\title{
Local design strategy in culture and communication of a person
}

\section{Chernjavskaya Valentina Stanislavovna}

The prof. of Philosophies and psychology department of the Vladivostok state university of economy and service, the doctor of pedagogical sciences, the professor, Vladivostok, Russia

\section{Email address:}

tina_v@rambler.ru (C. V. Stanislavovna)

\section{To cite this article:}

Chernjavskaya Valentina Stanislavovna. Local Design Strategy in Culture and Communication of a Person. Psychology and Behavioral Sciences. Vol. 2, No. 1, 2013,pp. 1-4. doi: 10.11648/j.pbs.20130201.11

\begin{abstract}
The statements of the approach to the design of a suit, as a component of culture and communication are motivated. The data of empirical study of the degree of consciousness (reflexivity) in clothing choice as a local design strategy of society is introduced.
\end{abstract}

Keywords: Design, Clothes Choice, Degree of Motives Reflection (Consciousness)

\section{Introduction}

One of the most important functions of social science is to create images of the future, which is designed to be guided by social innovations. Creating an image of society hasan important social and constructivist constituent. This image influences largely on what kind of society we are building. The role of psychology for a modern person in our country is relatively small.

Academician AG Asmolov notes that formal logic cannot explain that "personality", as an element of "a social system", can not only involve the social system, but also potentially lead it to some changes [1. P. 6]. Worldview (philosophical) task of psychology is to mentalize economic and centric image of our society by orienting its development, showing the social relevance in this important "business". [2]

Design as a creative professional activity has a high educational potential and numerous psychological possibilities to develop personalityand professional competence and identity of future designers, if they are included in the process of professional development in accordance with its logic and purpose. Understanding design as the world of form which has little influence on the life content hinders valuable attitude to the professional activity of designers and design education.

\section{Main Body}

A.A. Meschaninov defines design as a profession connected with "spiritualization of the process of using utilita- rian material objects", giving them a sense that allows a person to adopt objects of his environment sensually, make them a part of the consumption culture and include them in his interaction sphere [3, p. 103]. Particular urgency of design in Russia is connected with the fact that we continue being behind developed countries in the field of innovation and this gap is getting larger, while it is the design that is associated with uncertainties and risks of the initial stages of anyinnovative product development.

Garment is an important instrument of space social organization and the product of design. It acts as a "system of meaningful social connections." Creating clothes, hats and shoes, a man tries to meet his daily wants (essential needs, daily living needs).

This issue was considered by representatives of philosophical, cultural, psychological and sociological schools. M. Cole, M. Kiloshenko, TG Stefanenko consider psychological aspect of garment and fashion, AB Hoffman, PY Gontmakher AI Egorova study its cultural and historical context, ZV Sikevich, EB Plaksina etc. proof the philosophical foundations of the garment.

According to M. Cole the phenomenon of the garment in the cultural-historical psychology is based on his thesis that "culture" is something that is not "nature". It is a part of human environment, created by the man himself. Everything, even the simplest objects, created by man, every thought that arose in his mind belongs to Culture. It has been recognized that the culture is "hard to think about." We cannot see the culture, as it is the environment in which we exist. Meeting other cultures we can consider our own culture as a subject for reflection. [4]. 
LS Vygotsky wrote that culture calls into existence some special forms of behavior, alters the functioning of the mindand brings new stories in the developing system of human behavior. Development of human psyche in the ontogeny and human history should be understood as the evolution of human activity. The words we pronounce, the clothes we wear, the social institutions activities we are involved in, artificial physical objects we use are tools and symbols simultaneously. [5].

According to M. Cole, in the process of human culture forming cultural mediation and reflection creates such type of development when the activities of previous generations are accumulated in the present as a specific component of human environment. Social world affects the individual not only through the actions of real people who talk, communicate, give an example or convince, but also through the invisible ways of actions and objects created by other people in the surrounding world, including the garment [4].

There are preset forms of social interaction: customs, patterns, scripts, plays, rituals, cultural forms. All these elements make up the material and spiritual products of human life. This form of development, in turn, assumes special significance of social world for human development, because only the other people can create special conditions for this development $[4,5,6]$. This shift in the status of culture in relation to the psyche and behavior leads to a number of methodological issues [7]. The focus is on the necessity of considering culturally mediated or reflexive behavior in process to detect dynamic interactions combining different aspects of living.

In the process of historical development, people are change the ways and means of their behavior, transform their natural potential and functions, generate and create new, specifically cultural forms of behavior [8, 9, 10]. Modern men achieve higher levels of performing activities in each area and demonstrate high interdependence of social and technological skills [7].

Garment is an important instrument of space social organization. It acts as a "system of meaningful social connections."

Creating clothes, hats and shoes, a man doesnot try to meet only his daily needs. Garment, as a visual complex, has always accompanied its owner, reflecting the concepts and values, that couldn't not be expressed so equivalently and permanently by other means.

As we see it, professional education of clothes designers includes not only active use of their professional techniques and tools, but also,to a considerable degree, theknowledge and the results of Humanities. Professional training of clothes designers and its psychological foundation arecomplicated by the existing contradictions between the modern society demandfor specialists in design, capable of making modern, forward-looking and consciousdesigning decisions and working out aesthetic concepts adequate to developing cultural, social and economic, scientific processes, on the one hand, and insufficient clothes designers' understanding of its influence on the identity of the person who is wearing it, understands it as a cultural artifact associated with his own or another culture and designs it as a subject of his self-actualization. [8].

State and society requirements to the higher professional education involve, on the one hand, the demand for future specialists in this field on labour-marketand, on the other hand, meeting the modern consumer requirements in goods and services.

There is a variety of common ideas about the reasons for clothing choice. In our opinionthe most primitive one is that the choice is determined by the concept of price and material resources as the basis for clothes choice. Another point of view presents correspondence ofclothes to certain role images of the subject of choice as the reasons for choosing, because it facilitates his contact with the target group.

We share the position of E.A. Petrova, who, considering the sign system of a garment, believes that people hardly realize what they wear, and at the same time the sign system of a garment is intentional, i.e. it is directed and can be purposely used or not used in people communication. [9].

Reflexive possibility of such approach is connected with the opportunity to distinguish several degrees of sensibleness, reflexive understanding of informationgiven through the clothes. All elements of sign system can be realized. Thus, the level of sensibleness of the personality localdesign-strategies can be revealed.

Representatives of modern psychoanalysis (K.Konig, H.Kokhut) and humanistic psychology (A.Maslou) consider that many person preferences and choices cannot be realized including the choice of the professional activitytype, the clothes choice, attitude to work, time, and money and so on.

\section{Results and Discussion}

The analysis of R. Bart, V.I.Ilyin, I.S.Kon researches showed that the women'sclothes choice motivation has mostly been defined by the norms of the patriarchal society. These norms preset different functions to men and women. Males win females' attention by their actions proving their belonging to the "stronger sex", and women use their appearance. That's why the special function of women's clothing, body and jewelry is to make women attractive, "attract" men'seyes and souls. For many centuries women have been performing a decorative function in dominating estates and classes. As a result there are extremely nonfunctional clothes in which it was possible to show yourself but it was impossible to work. Even when an era of capitalism came the businessmen'swives were still "walking show-windows" of their husbands'economic and political successesfor decades.

The purpose of our empirical study is identification of true (reflexive), and hidden (not reflexive) motives (social and psychological determiners) for choosing clothes by women $(\mathrm{N}=156)$. (This study was performed together with our post-graduate student R. M. Gimayeva 2006 - 2012) [10].

For the research of nonconscious (not reflexive) social 
and psychological determiners of female consumer preferences in choosing clothes we usedmodified by us methodologyof psychosemantic diagnostics of hidden motives of different types of activity. (I.L.Solomin, 2003).

The generalized results of social and psychological determiners research of female consumer preferences in choosing clothes are given in table 1 .

Table 1. Comparison of the results of the research of conscious andnonconscious social and psychological determiners of consumer preferences in choosing clothes (\%) (We marked the determiners with statistically significantdistinctions).

\begin{tabular}{|c|c|c|c|c|}
\hline $\begin{array}{l}\text { Motive } \\
\text { for } \\
\text { clothes choice }\end{array}$ & $\begin{array}{l}\text { Conscious } \\
\text { choice }\end{array}$ & $\begin{array}{l}\text { Nonconscious } \\
\text { choice }\end{array}$ & Гэмп. & $\begin{array}{l}\text { Level } \\
\text { of } \\
\text { significance(P) }\end{array}$ \\
\hline $\begin{array}{l}\text { Appearance, } \\
\text { figure(form) }\end{array}$ & 63,8 & 40,3 & 1,89 & 0,05 \\
\hline $\begin{array}{l}\text { Individuality, } \\
\text { Ego }\end{array}$ & 53,1 & 41,2 & 2,21 & 0,01 \\
\hline Comfort & 61,5 & 15,9 & 3,51 & 0,01 \\
\hline Quality & 50,2 & 13,8 & 3,52 & 0,01 \\
\hline Style & 31,3 & 9,8 & 2,54 & 0,01 \\
\hline Self-expression & 28,8 & 27,7 & 0,19 & 0,05 \\
\hline Fashion & 27,2 & 25,2 & 0,24 & 0,05 \\
\hline Selfestimation & 13,8 & 14,4 & 0,18 & 0,05 \\
\hline Utility & 21,7 & 16,3 & 1,09 & 0,01 \\
\hline Feminity & 15,4 & 16,3 & 0,1 & 0,05 \\
\hline Unusualness & 10,8 & 22,5 & 2,36 & 0,01 \\
\hline Prestige & 3,8 & 20,4 & 2,64 & 0,01 \\
\hline Status & 3,5 & 17,7 & 2,56 & 0,01 \\
\hline Sexuality & 3,2 & 20,1 & 2,65 & 0,01 \\
\hline Recognition & 10,2 & 19,7 & 2,14 & 0,01 \\
\hline Male's interest & 2,3 & 27,8 & 2,85 & 0,05 \\
\hline $\begin{array}{l}\text { Looking } \\
\text { well-groomed }\end{array}$ & 0 & 13,7 & & \\
\hline Tradition & 0 & 15,0 & & \\
\hline Elegance & 0 & 20,0 & & \\
\hline My body & 0 & 17,5 & & \\
\hline
\end{tabular}

Research of conscious motives for choosing clothes by women showed that for the majority of women the most significant motives of the choice are "appearance" and "figure", "my identity", and also "convenience" and "quality" of clothes. Such motives of the clothes choice as: "style", "self-expression", "fashion", "self-estimation", "femininity" are on the average level in the range of options. Thus, a small amount of women consciously choose clothes because of such motives as "prestige", "status", "sexuality", "male's interest". The nonconscious (latent) motivation of the women's choice of clothes differs from the conscious one. Choosing clothes nonconsciously fewer women had such choice motives as "appearance" and "figure", "my identity" and "Individuality or Ego", "convenience", "quality", and "style". At the same time such motives of the clothes choice as "male's interest ", "sexuality", "originality", "prestige", "status", "recognition" in comparison with a conscious choice were revealed among the majority of women. Distinctions between conscious and nonconscious motivation of the clothes choice reached the level of the statistical importance on following motives: "appearance and figure", "Individuality or Ego", "convenience", "male's interest", "quality", "sexuality", "style", "originality", "prestige", "status", "recognition". Consciously women more often choose "appearance and figure", "Individuality or Ego" as motives of the clothes choice. That might designate the fact that women first of all "wear clothes for themselves" but according to diagnostics of nonconscious motivation women allocate such motives as "prestige", "status", "recognition ", "male's interest" in comparison with a conscious choice more often. It testifies that while choosing clothes women are more focused on society and people around, than it is realized by them.

\section{Conclusions}

The least conscious motives for clothes choice are: "male's interest", "sexuality", "prestige", "status". Apparently, focus of women's clothing on drawing men'sattention is so deep and natural that it isn't realized in each individual case of a choice. Besides, these determiners of the clothes choice can be hidden, because they are not approved by society. At the same time orientation to "Individuality or Ego", "appearance' prevails over "male's interest" both at conscious and nonconscious choices and wins the first place among motives of the clothes choice.

Thus, in a sample group of 156 people of different age and social status, social and psychological determiners of female consumer preferences were defined. These determiners are components of the motivational sphere and that is whythey differ on the degree of consciousness of local design strategy of the personality positioned in society.

In the present article we draw a parallel between consciousness and reflexivity, however further researches assume more structured reflexive approach in realization of the research strategy.

\section{Acknowledgments (optional)}

Gimaeva Rita Masnaviovna.

\section{References}

[1] Асмолов, А.Г. Культурно-историческая психология и конструирование миров / А.Г. Асмолов. - М.: Изд-во «Институт практической психологии», 1996. - 768 с.

[2] Юревич, А.В. Социальная релевантность и социальная ниша психологии / А.В. Юревич // Психологи ᄀческий журнал. - 2006. - № 4.

[3] Мещанинов, А.А. Дизайн. Точка над й / А.А. Мещанинов. - СП.б.: Изд-во Политех. ун-та, 2008. - 220с.

[4] Коул, М. Культурно-историческая психология / М. Коул. 
- М.: Когито-центр, 1997. - 326 с.

[5] Выготский, Л.С. Вопросы теории и истории психологии / Л.С. Выготский; под ред. А.Р. Лурия, М.Г. Ярошевского. - М.: Педагогика, 1982. Т. 1. -488 с.

[6] Канеман, Д. Карты ограниченной рациональности: психология для поведенческой экономики / Психологический журнал. - 2006. - № 2. - С. 5-28.

[7] Шевцов, А.А. Общая культурно-историческая психология / А.А. Шевцов. - СПб.: Тропа Троянова, 2007. -407 c. 5.

[8] Кравцова Т.А., Чернявская, В.С. Гуманитарно-художественная компетентность дизайнера костюма / монография. - Владивосток: Изд-во ВГУЭС, 2009. $-164 \mathrm{c}$.

[9] Петрова Е.А. Роль и функции одежды в жизнедеятельности человека. Сообщ. 2 // Швейная промышленность. - 1999. - №4. - С. 36-38.

[10] Чернявская $\quad$ B.C., Гимаева $\begin{array}{lrr}\text { Чернявская } & \text { B.С., } & \text { Гимаева } \\ \text { Социально-психологические } & \text { детерминанты }\end{array}$ потребительских предпочтений современных женщинособенности мотивации потребителей продуктов творческой деятельности // Мир науки, культуры, образования. - Горно-Алтайск, 2010. - № 4 (23). C.145-149.

[11] Asmolov, A.G. Kul'turno-istoricheskaja psihologija i konstruirovanie mirov / A.G. Asmolov. - M.: Izd-vo «Institut prakticheskoj psihologii»», 1996. - $768 \mathrm{~s}$.
[12] Jurevich, A.V. Social'naja relevantnost' i social'naja nisha psihologii / A.V. Jurevich // Psihologi `cheskij zhurnal. 2006. - № 4 .

[13] Meshhaninov, A.A. Dizajn. Tochka nad j / A.A. Meshhaninov. - SP.b.: Izd-vo Politeh. un-ta, 2008. - 220s.

[14] Koul, M. Kul'turno-istoricheskaja psihologija / M. Koul. M.: Kogito-centr, 1997. - $326 \mathrm{~s}$

[15] Vygotskij, L.S. Voprosy teorii i istorii psihologii / L.S. Vygotskij; pod red. A.R. Lurija, M.G. Jaroshevskogo. - M.: Pedagogika, 1982. T. 1. $-488 \mathrm{~s}$.

[16] Kaneman, D. Karty ogranichennoj racional'nosti: psihologija dlja povedencheskoj jekonomiki / Psihologicheskij zhurnal. - 2006. - № 2. - S. 5-28.

[17] Shevcov, A.A. Obshhaja kul'turno-istoricheskaja psihologija / A.A. Shevcov. - SPb.: Tropa Trojanova, 2007. - 407 s. 5.

[18] Kravcova T.A., Chernjavskaja, V.S. Gumanitarno-hudozhestvennaja kompetentnost' dizajnera kostjuma / monografija. - Vladivostok: Izd-vo VGUJeS, 2009. - 164 s.

[19] Petrova E.A. Rol' i funkcii odezhdy v zhiznedejatel'nosti cheloveka. Soobshh. 2 // Shvejnaja promyshlennost'. - 1999. - №4. - S. 36-38.

[20] Chernjavskaja V.S., Gimaeva R.M. Social'no-psihologicheskie determinanty potrebitel'skih predpochtenij sovremennyh zhenshhin- osobennosti motivacii potrebitelej produktov tvorcheskoj dejatel'nosti // Mir nauki, kul'tury, obrazovanija. - Gorno-Altajsk, 2010. - № 4 (23). S.145-149. 